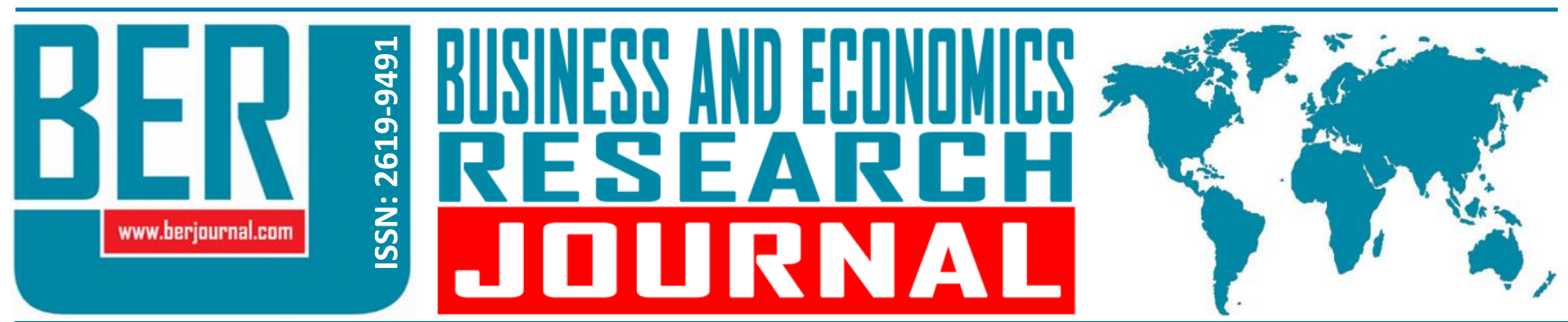

Business and Economics Research Journal Vol. 11, No. 3, 2020, pp. 753-767 doi: 10.20409/berj.2020.280

\section{Maddi Duran Varlıklar ve Amortismanlar Açısından TFRS, BOBİ FRS, KÜMİ FRS Taslağı ve MSUGT'daki Uygulamaların Karşılaştırılması}

Anahtar Sözcükler: Finansal Raporlama Çerçeveleri, Maddi Duran Varlıklar, KÜMi FRS

JEL: K34, M40, M41, M48

\begin{tabular}{|c|c|}
\hline Geliş & 20 Nisan 2020 \\
\hline Düzeltme & : 03 Haziran 2020 \\
\hline Kabul & 17 Haziran 2020 \\
\hline
\end{tabular}

\section{Comparison of TFRS, BOBI FRS, KUMI FRS and General Communiqué on Application of Accounting System (MSUGT) in terms of Tangible Fixed Assets and Depreciation}

\begin{abstract}
Tangible fixed assets have an essential place in the balance sheet, and accurate calculation of costs, valuation, depreciation, and accurate presentation of related financial statements are crucial. There are regulations in Turkish Financial Reporting Standards (TFRS), Financial Reporting Standard for Large and Medium-sized Entities (BOBI FRS), Financial Reporting Standard for Small and Micro Entities (KUMI FRS) and General Communiqué on Application of Accounting System (MSUGT) tax applications related to tangible fixed assets. The purpose of this study, which is carried out by scanning standards and legislative provisions, is to identify similar and different aspects by comparing these regulations that form different reporting frameworks. In addition, emphasizing the differences and similarities between standards and tax regulations used in MSUGT applications and contributing to the literature and applications are among the aims of the study. As a result, even though there are many similarities within the framework of TFRS, BOBI FRS, and KUMI FRS draft, borrowing costs and delay interest separation issues are different among standards. However, there are essential differences between tax regulation and standards that aim informational reporting, especially in terms of depreciation and measurement in the following periods.
\end{abstract}

Keywords: Financial Reporting Frameworks, Tangible Fixed Assets, KUMI FRS

JEL: K34, M40, M41, M48
Received : 20 April 2020

Revised : 03 June 2020

Accepted : 17 June 2020

\footnotetext{
Cite this article as: Aytac, A \& \& Gucenme-Gencoglu, U. (2020). Maddi duran varlıklar ve amortismanlar açısından TFRS, BOBi FRS, KÜMi FRS taslağı ve MSUGT'daki uygulamaların karşılaştırılması. Business and Economics Research Journal, 11(3), 753-767.

a Res. Asst., Bursa Uludag University, Faculty of Economics and Administrative Sciences, Department of Business Administration, Bursa, Turkiye, alpaytac@uludag.edu.tr (ORCID ID: 0000-0003-4949-4884)

b Prof., PhD., Bursa Uludag University, Faculty of Economics and Administrative Sciences, Department of Business Administration, Bursa, Turkiye, umitgucenme@uludag.edu.tr (ORCID ID: 0000-0002-8034-9063) 


\section{Giriş}

İşletme yönetimine ve işletme ile ilgili taraflara bilgi sağlayan muhasebe bilgi sisteminin doğru ve güncel verilerden oluşması, stratejik kararlar açısından hayati önem taşımaktadır. Bu bilgiler, vergi kaygısıyla hazırlanmayan, gerçeğe ve intiyaca uygun, anlaşılabilir, doğrulanabilir ve karşılaştırılabilir ise, ilgili tarafların kararlarına dayanak oluşturabilir. Bu nitelikleri taşıyan bilgilerin raporlandığı finansal tablolar, uluslararası normlara uygun finansal raporlama standartlarındaki düzenlemeler ile sağlanmaktadır. Ülkemizde bağımsız muhasebe denetimine tabi işletmeler, Türkiye Muhasebe/Finansal Raporlama Standartları (TMS/TFRS) ile Büyük ve Orta Boy İşletmeler İçin Finansal Raporlama Standardı (BOBi FRS)'nı uygulamaktadırlar. Denetime tabi olmayan küçük ve mikro işletmeler ise halen, 1994 yılından bu yana uygulanan Muhasebe Sistemi Uygulama Genel Tebliği (MSUGT) kapsamındaki Tekdüzen Muhasebe Sistemi'ni kullanmaya devam etmektedirler. Ancak bu işletmelerin de, bilgi amaçlı raporlama yapmasını sağlamak için, ülkemizde uygulanan raporlama standartlarındaki düzenlemeler ile uyumlu ancak vergi uygulamalarımıza daha yakın olan bir finansal raporlama taslağı, Kamu Gözetimi Kurumu (KGK) tarafından hazırlanmış bulunmaktadır. Bu makalenin amacı, işletmelerin finansal tablolarında önemli bir paya sahip olan maddi duran varlıklar ile ilgili düzenlemeleri, bu raporlama çerçeveleri kapsamında karşılaştırmaktır. Maddi duran varlıklar ile ilgili farklı uygulamalar hem finansal durum tablosundaki hem de kar zarar tablosundaki rakamların farklılaşmasına ve ilgili tarafların kararlarını önemli derecede etkilemesine neden olmaktadır.

Maddi duran varlıkların kullanım sürelerinin uzun olması nedeniyle her yıl ilk edinim maliyetleri ile finansal durum tablosunda raporlanması, maliyet değerinde ortaya çıkan artış ve azalışların dikkate alınmaması halinde, bir süre sonra finansal durum tablosunun güncel verileri yansıtmamasına neden olmaktadır. Öte yandan her yıl aynı maliyet değeri üzerinden amortisman ayrılması, yıllık amortisman giderlerinin gerçek değer azalışlarının kar veya zarar tablosuna yansıtılmaması sonucunu doğurmaktadır. Bu ve benzeri sorunlar ile ilgili, maddi duran varlıkların ve amortismanların kaydı ve raporlanması konusunda farklı raporlama çerçevelerinde farklı uygulamalar bulunmaktadır. Bu çalışmada, finansal raporlama çerçevelerindeki ve vergi mevzuatımızdaki maddi duran varlıklara yönelik hükümler incelenmiştir. Bu kapsamda, TMS/TFRS, BOBi FRS, KÜMi FRS Taslağı, MSUGT uygulamalarında kullanılan vergi kanunlarındaki maddi duran varlıklar ve amortismanlar ile ilgili düzenlemeler arasındaki farkların belirlenmesi, raporlama açısından bir karşılaştırma yapılması amaçlanmıştır. Bu amaçla önce Türkiye'deki raporlama çerçeveleri hakkında kısaca bilgi verilmiş, daha sonra raporlama çerçevelerindeki ilgili düzenlemeler taranarak karşılaştırmalar yapılmış, benzerlikler ve farklılıklar vurgulanmaya çalışılmıştır.

\section{Türkiye'deki Raporlama Çerçeveleri}

Kamu Gözetimi Muhasebe ve Denetim Standartları Kurumu (KGK) tarafından uygulama kapsamı, "Kamu Yararını Ilgilendiren Kuruluşlarla (KAYiK)" sınırlandırılmış olan ve ülkemizde 2005 yılından bu yana kullanılan "Türkiye Muhasebe/Finansal Raporlama Standartları" (TMS/TFRS) ile KGK tarafından 2017 yılında yayımlanan ve 2018 yılı başından itibaren kullanılan "Büyük ve Orta Boy İşletmeler için Finansal Raporlama Standardı (BOBi FRS)", bağımsız denetime tabi olan işletmeler tarafından uygulanmak zorundadır. Ancak ülkemizde bilanço esasına göre defter tutan ve bağımsız denetime tabi olmayan küçük ve mikro işletmeler, 1994 yılından itibaren yasal kayıtların tutulmasında kullanılan ve denetime tabi olan işletmelerin raporlama çerçevelerinin gereklerini karşılamayan "Muhasebe Sistemi Uygulama Genel Tebliği (MSUGT)" kapsamındaki Tekdüzen Muhasebe Sistemi'ni kullanmaya devam etmektedirler. KGK, ülkemizdeki tüm finansal raporlama çerçevelerinin uyumunu sağlamak amacıyla bu işletmeler için 2019 yılında, Küçük ve Mikro İşletmeler İçin Finansal Raporlama Standardı Taslağı (KÜMi FRS)'nı hazırlamıştır (Gücenme Gençoğlu, 2020: 1).

Muhasebe bilgi sistemi, "işletme faaliyetlerini planlamak, kontrol etmek ve yönetmek amacıyla bilgi kullanıcılarının gereksinim duydukları bilgileri sağlamak için verileri ve mali nitelikli işlemleri süreçleyen ve onlara sunan bir bilgi sistemi" olarak tanımlanabilir. Muhasebe bilgi sistemi günümüze kadar en iyi şekilde geliştirilen ve uygulanan bilgi sistemidir (Şahin, 2007: 33-34). İşletmelerde bilgi sisteminin esas görevi, ilgili taraflara ihtiyaç duyulan bilgileri zamanında ulaştırmaktır. 
Muhasebe bilgi sisteminden elde edilecek finansal bilgilerin faydalı olması için sahip olması gereken niteliksel özellikler "Finansal Raporlamaya Iliş̧in Kavramsal Çerçeve'de temel niteliksel özellikler (ihtiyaca uygunluk, önemlilik, gerçeğe uygun sunum) ve destekleyici niteliksel özellikler (karşıllaştırılabilirlik, doğrulanabilirlik, zamanında sunum, anlaşılabilirlik)" olarak belirtilmiştir (Kamu Gözetimi Kurumu, 2018: 3334). Finansal bilgi kullanıcıları, işletme ile ilgili bilgi sahibi olmak istediklerinde, raporlayan işletmeye ait bilgilerin diğer işletmelere ait benzer bilgileriyle ve aynı işletmenin başka dönemine veya başka tarihe ait benzer bilgileri ile karşılaştırılabilir özellikte finansal bilgiye intiyaç duymaktadır. Yapılan uyumlaştırma çalışmaları ile işletmeler, farkı ülkelerde benzer işlemler ve olaylar için benzer kavramları ve muhasebe yöntemlerini uygulayarak finansal raporlamadaki farklılıkları azaltabilmektedir. Finansal raporlamada uyumlaştırma, standartlar yoluyla sağlanmaktadır. Uluslararası Muhasebe Standartları; muhasebede tekdüzeliğin sağlanabilmesi ve finansal bilgi kullanıcılarının ihtiyaç duyduğu bilgilerin, gerçeği yansıtan, doğru, güvenilir, anlaşıır ve karşılaştıılabilir olabilmesi için esas alınan ilke ve kurallardır. Bu standartlar, Uluslararası Muhasebe Standartları Kurulu (UMSK) tarafından oluşturulmakta, Türkiye'de ise, Uluslararası Muhasebe/Finansal Raporlama Standartları (UMS/UFRS) ile uyumlu Türkiye Muhasebe/Finansal Raporlama Standartlarının (TMS/TFRS) yayınlanması ve uygulanması Kamu Gözetimi Kurumu (KGK) tarafından yürütülmektedir.

"Büyük ve Orta Ölçekli İşletmeler için Finansal Raporlama Standardı (BOBi FRS)" ise, "bağımsız denetime tabi olup zorunlu veya ihtiyari olarak Türkiye Finansal Raporlama Standartlarını (TFRS) uygulamayan işletmelerin" kullanacakları raporlama çerçevesidir. 1 Ocak 2018'e kadar "Muhasebe Sistemi Uygulama Genel Tebliği (MSUGT) ve ilâve Hususlar'ı" uygulayan bu işletmelerin 1 Ocak 2018 tarihi ve sonrasında başlayan yıllık hesap dönemlerinde finansal tablolarını hazırlarken BOBi FRS'yi uygulamaları gerekmektedir. BOBi FRS'nin yer aldığı 29 Temmuz 2017 tarihli Tebliğ'de büyük işletme tanımı bulunmaktadır. Buna göre, "aktif toplamı 75 milyon ve üstü, yıllık net satış hasılatı 150 milyon ve üstü Türk Lirası ve ortalama çalışan sayısı 250 ve üstü olan ve bu üç ölçütten en az ikisinin eşik değerlerini, varsa bağlı ortaklıklarıyla birlikte, art arda iki raporlama döneminde aşan işletmeler müteakip raporlama döneminde büyük işletme olarak değerlendirilir". "Bu ölçütlerin altında kalan, ancak denetime tabi olma koşullarını karşılayan işletmeler ise standartta orta boy işletmelerin uyması gereken kurallara göre finansal raporlama yapmaktadır." "Uluslararası muhasebe ve finansal raporlama uygulamalarıla ve Avrupa Birliği (AB) düzenlemeleriyle uyumlu olan ve 27 bölümden oluşan BOBI FRS'de, orta büyüklükteki işletmeler için genel olarak maliyet esaslı bir finansal raporlama öngörülmüş; büyük işletmelere yönelik ise ilâve yükümlülükler getirilmiştir" (Gücenme Gençoğlu, 2017).

Bilgi amaçlı finansal tabloların hazırlanmasına imkân sağlayan bu finansal raporlama çerçevelerinin yanında ülkemizde ticari hayatı düzenleyen Türk Ticaret Kanunu (TTK) 64'üncü maddesinin beşinci fıkrası uyarınca "gerçek ve tüzel kişiler vergi mevzuatında yer alan defter tutma ve kayıt zamanıyla ilgili hükümlere uymak zorundadır." Bu kapsamda, TMS/TFRS ve BOBI FRS'ye uygun olarak finansal tablo hazırlayan ve sunan işletmelerin vergi mevzuatına göre yapacakları kayıt ve raporlama sorumlulukları devam etmektedir. KGK tarafından yayımlanan "Finansal Tablo Örnekleri ve Kullanım Rehberi" uyarınca "TMS/TFRS'lere ve BOBi FRS'ye göre finansal tablolarını hazırlayanlar; bu tablolar ile vergi yasaları çerçevesinde hazırlanmış finansal tablolar arasındaki ilişkiyi kurmak, bir sonraki yıl finansal tablolarının sağlıklı bir şekilde hazırlanmasını sağlamak ve standartlar uyarınca hazırlayacakları finansal tablolara ulaşmak için yapacakları kayıtları göstermek üzere, TTK'nın 64 üncü ve 82'nci maddeleri çerçevesinde, varsa gerekli düzeltme işlemlerini ticari defterlerinden ayrı bir şekilde kaydedip saklamakla ve gerektiğinde ibraz etmekle yükümlüdür" (KGK, http://www.kgk.gov.tr). Tutulması zorunlu olmayan bu defterlere yapılacak yasal olmayan bu kayıtlar, işletmelerin standartlara uygun finansal raporların sağlıklı olarak hazırlanabilmesi için gerekli bilgilerin elde edilmesini sağlamaktadır.

Ülkemizde 1994 yılından bu yana yasal kayıtlar için kullanılan MSUGT kapsamındaki düzenlemeler ve vergi kanunlarımızdaki değerleme ölçüleri ile hazırlanan finansal tablolar, TFRS'nin gereklerini karşılamamaktadır. MSUGT'lara göre hazırlanan finansal genellikle Vergi Usul Kanunu'ndaki değerleme ölçüleri esas alındığından bu tablolar, "mükelleflerin vergi karşısındaki durumunu göstermek amacıyla kullanılmış, gerçeğe ve ihtiyaca uygun, karşılaştırılabilir bilgi sağlama amacından uzaklaşmıştır." Bu nedenle 
ülkemizdeki tüm finansal raporlama çerçevelerinin uyumunu sağlamak amacıyla KGK tarafından, "Küçük ve Mikro İşletmeler İçin Finansal Raporlama Standardı (KÜMi FRS) Taslağı" hazırlanmış ve 12 Temmuz 2019 tarihi itibariyle kamuoyunun görüşüne açılmıştır. TMS/TFRS'lere ve BOBi FRS'ye göre uygulanması daha kolay ve daha az maliyetli olan, uluslararası finansal raporlama uygulamalarıyla tutarlı, daha ziyade BOBi FRS ile uyumlu fakat ülkemizdeki vergi uygulamalarına diğerlerinden daha yakın olan ve bilgi için finansal tablo düzenlenmesinde kullanılması amaçlanan KÜMi FRS'nin zaman içinde Tekdüzen Muhasebe Sisteminin yerine geçmesi beklenmektedir. Tekdüzen Muhasebe Sisteminde varlıkların değerlemesine ilişkin düzenlemeler bulunmadığından, bu sistem içinde raporlama yapılırken Vergi Usul Kanunu'nda yer alan değerleme hükümleri uygulanmıştır. Bu nedenle çalışmamızdaki karşılaştırmalarda, MSUGT ve vergi uygulamaları aynı başık altında ele alınmıştır.

Maddi duran varlıklar ile ilgili düzenlemeler TMS 16 "Maddi Duran Varlıklar" ve TMS 36 "Varlıklarda Değer Düşüklüğü" standartları içinde yer almaktadır. BOBi FRS'de ise Bölüm 12 "Maddi Duran Varlıklar" ve Bölüm 18 "Varlıklarda Değer Düşüklüğü" ile ilgili düzenlemeleri içermektedir. KÜMi FRS'de maddi duran varlıklar ile ilgili düzenlemeler Bölüm $11^{\prime}$ de, varlıklarda değer düşüklüğü ile ilgili düzenlemeler ise Bölüm 16 'da yer almaktadır.

Maddi duran varlıklar ile ilgili vergiye esas değer, Vergi Usul Kanunu (VUK) ve VUK Genel Tebliğleri ile düzenlenmiştir. Maddi duran varlıkların raporlanmasındaki temel konular; varlıkların elde etme maliyetlerinin tespiti, defter değerlerinin belirlenmesi ve bunlarla ilgili olarak finansal tablolara yansıtılması gereken değerleme farkları ve amortisman tutarlarının hesaplanması ve raporlanmasıdır. Çalışmamızda bu hususlar her bir raporlama çerçevesi için ayrı başıklarda ele alınmaktadır.

\section{Finansal Raporlama Çerçevelerine Göre Maddi Duran Varlıkların ilkk Kaydı ve Maliyet Değerinin Tespiti}

Finansal raporlama çerçevelerini oluşturan standartlarda finansal tablo kalemlerinin ölçümüne önem verilmiş ve yeni ölçüm esasları sunulmuştur. Ölçüm aslında yıllardır yasal mevzuatımızda yer alan değerleme işlemidir. "Muhasebe standartlarında değerleme yerine ölçüm kavramı kullanılmaktadır. Muhasebede ölçüm (değerleme), işletme faaliyetlerine, varlık ve borçlara parasal bir değer tayin edilmesi sürecidir." Tarihi maliyet ölçüsü geleneksel olarak "güvenilir, uygulanması kolay ve ucuz" olması açısından uzun yıllardır benimsenmiştir. Ancak standartlarda belirtilen "finansal tablolara dayalı olarak geleceğe yönelik kararlar alma" işlevini tarihi maliyetlerle düzenlenmiş finansal tabloların yerine getirmesi olanaksız görüldüğünden, tarihi maliyet ve gerçeğe uygun değerin kullanıldığı karma bir ölçüm sistemi oluşturulmuştur. Standartlarda ilk kayıtlamada büyük ölçüde tarihi maliyetin benimsendiği, ancak sonraki dönemlerde yapılan ölçümlerde ise, cari değer esasına dayalı ölçüme bir yöneliş olduğu görülmektedir.

\subsection{TMS 16'ya Göre Illk Kayıt ve Maliyet Değerinin Tespiti}

Maddi duran varlıklar, ancak, gelecek dönemlerde işletmeye ekonomik fayda sağlamalarının muhtemel olması ve maliyetlerinin güvenilir bir biçimde ölçülebilmesi halinde mali tablolara alınır. Yedek parça, yardımcı donanım ve servis donanımı gibi kalemler, maddi duran varlık tanımını karşılamaları durumunda, bu standart uyarınca muhasebeleştirilir. Aksi halde söz konusu kalemler stok olarak sınıflandırılır. Buna göre eğer bir varlığın alımı, ilişkili varlıkların işletmeye gelecekte sağlayacağı ekonomik yararı artırıyor ise, bu kalemler maddi duran varlık olarak muhasebeleştirilir. Örneğin bir kimyasal madde üreticisi, çevre düzenlemelerine uymak için tehlikeli kimyasal maddelerin üretimi ve depolanması için yeni kimyasal maddelerin kullanım süreçleri tesis edebilir. İşletme ilgili tesis düzenlemeleri olmaksızın kimyasal maddeleri üretip satamayacağından, bunlar varlık olarak muhasebeleştirilir.

Standartlara göre, arsa ve binalar birlikte alındıklarında dahi ayrılabilir maddi duran varlıklar olarak kabul edilir ve ayrı olarak muhasebeleştirilmesi gerekir. Çünkü arsa sınırsız ömre sahip olduğundan amortisman uygulanmaz.

TMS 16'ya göre, "maddi duran varlıklar, ilk kayda almada maliyet bedeliyle ölçülür. Satın alınan maddi duran varlığın maliyet bedeli; ticari iskontolar ve indirimler çıkarıldıktan sonraki satın alma fiyatından, satın 
alma işlemine bağlı olarak yapılan giderlerden ve varlığın yönetim tarafından amaçlanan koşullarda kullanılabilmesini sağlayacak konuma ve duruma getirilmesiyle doğrudan ilişkilendirilebilen maliyetlerden oluşur. Işletmece inşa edilen varlıkların maliyetleri de iktisap edilen varlıklarla aynı ilkelere göre belirlenir. Bir varlığın işletmece imal edilmesinde kullanılan normalin üzerindeki tutarda artık madde, iş gücü veya diğer kaynaklar varlığın maliyetine dahil edilmez."

Borçlanma maliyetlerinin işletmece inşa edilen maddi duran varlık kaleminin defter değerinin bir unsuru olarak muhasebeleştirilmesine ilişkin ilkeler "TMS 23 Borçlanma Maliyetleri" ile belirlenmiştir. TMS 23'e göre borçlanma maliyetindeki temel yöntem bunların, "niteliğine ve yöntemine bakılmaksızın dönem gideri olarak kaydedilmesidir. Sadece özellikli bir varlığın satın alınması, inşası veya üretimi ile doğrudan ilgisi bulunan borçlanma maliyetleri aktifleştirilebilir. Özellikli varlıklar; satılabilir duruma getirilmesi uzun bir süreyi gerektiren stoklar, üretim tesisleri, enerji üretim santralleri ve inşa edilmekte olan yeraltı ve yerüstü düzenleri ile binalar olarak" sıralanmıştır.

TMS 16, 23'üncü maddeye göre "vadeli varlık alımlarında, peşin bedel ile toplam ödeme arasındaki fark, kredi dönemi boyunca faiz olarak finansal tablolara yansıtılır." Buna göre maddi duran varlık kaleminin maliyeti, muhasebeleştirme tarihindeki peşin fiyatın eşdeğeri tutardır. Vadeli fiyat ile peşin fiyat arasındaki fark, TMS 23 "Borçlanma Maliyetleri" standardında aktifleştirmeye izin verilen durumlar hariç, kredi dönemi boyunca faiz gideri olarak mali tablolara alınır.

Maddi duran varlıkların takas yoluyla ediniminde izlenecek yollar TMS 16 madde 24 ve 25 kapsamında düzenlenmiştir. Buna göre, "bir maddi duran varlık takas yoluyla edinildiğinde, edinilen varlığın maliyeti gerçeğe uygun değer ile ölçülür. Ancak; takas işleminin ticari niteliği yoksa veya ne elde edilen varlığın ne de elden çıkarılan varlığın gerçeğe uygun değeri güvenilir bir şekilde ölçülemiyorsa; varlığın maliyeti, elden çıkarılan varlığın defter değeri ile ölçülür. Eğer elde edilen varlıktan kaynaklanacak nakit akışları (risk, zamanlama ve tutar olarak) transfer edilen varlıktan kaynaklanacak nakit akışlarından farklı ise, takas işlemi işletmenin faaliyetlerini etkiliyorsa ve bu etki takas edilen varlıkların gerçeğe uygun değerine göre önemli ise, takas işleminin ticari niteliği vardır ve varlık belirlenebiliyor ise gerçeğe uygun değer ile değerlenir. TMS 16'ya göre, takas yoluyla edinilen maddi duran varlığın elde etme maliyeti, belirlenebiliyor ise alınan varlığın gerçeğe uygun değeri ile belirlenemiyorsa vazgeçilen varlı̆̆ın gerçeğe uygun değerinden ya da vazgeçilen varlığın defter değeri ile belirlenebilir."

\subsection{BOBi FRS'ye Göre Illk Kayıt ve Maliyet Değerinin Tespiti}

BOBI FRS'ye göre, maddi duran varlıklar, ilk kayda almada maliyet bedeliyle ölçülür ve maliyet bedelinin tespiti TMS 16 ile uyumlu olmakla birlikte, vadeli alımlarda maliyetin tespitinde bazı farklılıklar bulunmaktadır. BOBi FRS'de bir yıllık vade esas alınmıştır. BOBi FRS Bölüm 12, 9 uncu maddeye göre "Bir yıl veya daha kısa vadeli bir ödeme karşılığında satın alınan maddi duran varlıklar, vade farkı ayrıştırılmaksızın, ödenen veya ödenmesi beklenen nakit tutar üzerinden ölçülür. Bir yıldan uzun vadeli bir ödeme karşllı̆ında satın alınan maddi duran varlıklar ise, vade farkı ayrıştırılarak peşin fiyat üzerinden (diğer bir ifadeyle işletme peşin ödeme yapmış olsaydı ödeyeceği fiyat üzerinden) ölçülür, vade farkı tutarı, etkin faiz yöntemine göre hesaplanan faiz gideri olarak muhasebeleştirilir."

BOBI FRS 'de, "maddi duran varlıklara ilişkin borçlanma maliyetleri, oluştukları dönemde kâr veya zarara yansıtılmaktadır. Sadece, inşası normal şartlar altında bir yıldan daha uzun süren maddi duran varlıklar için katlanılan borçlanma maliyetleri kullanıma hazır hale geldiği tarihe kadar maddi duran varlığın maliyetine dâhil edilmektedir." Bu durum TMS 16'da (TMS 23 Borçlanma Maliyetleri standardına atıfta bulunarak) "özellikli varlık niteliğinde olan maddi duran varlıklar için geçerli olup bu tür varlıklar tamamlanana kadar ilgili borçlanma maliyetleri varlığın maliyetine eklenmekte, daha sonra ortaya çıkan borçlanma maliyetleri ise gider yazılmaktadır (Ataman, 2017: 161).

TMS 16 ile uyumlu olarak, "yedek parça ve bakım malzemeleri, maddi duran varlık tanımını karşılaması durumunda maddi duran varlık olarak raporlanır. Aksi halde bu varlıklar, stoklar içerisinde sınıflandırılır. Edinimden sonra maddi duran varlıklar için yapılan harcamalar, yenileme harcamaları ve büyük çaplı kontroller için yapılan harcamalar gibi varlığın ekonomik ömrünü uzatarak veya kapasitesini genişleterek 
kendisinden gelecekte elde edilecek faydayı artırıyorsa, ilgili maddi duran varlık maliyetine ilave edilir. Arazi ve binalar, birbirinden ayrılabilir varlıklardır ve söz konusu varlıklar birlikte edinilmiş olsalar bile, ayrı olarak muhasebeleştirilirler."

Takas yoluyla elde edilen maddi duran varlığın değeri, TMS 16'ya göre, işlemin ticari içeriği varsa ve gerçeğe uygun değeri tespit edilebiliyorsa, elde edilen varlığın veya elden çıkarılan varlığın gerçeğe uygun değeri ile ölçülür. Eğer gerçeğe uygun değeri tespit edilemiyorsa, elden çıkarılan varlığın defter değeri ile ölçülür." BOBi FRS madde 12'ye göre ise, "takas yoluyla edinilen maddi duran varlığın veya varlıkların maliyeti, elden çıkarılan parasal olmayan kalemin net defter değeri esas alınarak belirlenir. Takasta parasal bir kalem de alınmış veya verilmiş ise, elden çıkarılan parasal olmayan kalemin net defter değerine, ödenen parasal kalemin gerçeğe uygun değeri eklenir ya da elden çıkarılacak parasal olmayan kalemin net defter değerinden, alınan parasal kalemin gerçeğe uygun değeri indirilir."

\subsection{KÜMi FRS Taslağı'na Göre İlk Kayıt ve Maliyet Değerinin Tespiti}

KÜMi FRS Taslağı'nda da maddi duran varlıklar, ilk kayda almada maliyet bedeliyle ölçülür ve maliyet bedeli TMS 16 ve BOBi FRS Bölüm 12 ile uyumlu olarak satın alma bedeli ile satın alma işlemine bağlı olarak yapılan giderlerden oluşur. Ancak vadeli alımlarda TMS 16 ve BOBi FRS'den farkı olarak faiz ayrıştırması yapılmaz, bu nedenle vergi uygulamalarımızda olduğu gibi maliyet değerinin içinde vade farkı da yer almaktadır.

TMS 16 ve BOBi FRS ile uyumlu olarak, bir varlığın ediniminden sonra kullanım süresi içinde varlıkla ilgili olarak varlığın ekonomik ömrünü uzatarak veya kapasitesini genişleterek kendisinden gelecekte elde edilecek faydayı artıran harcamalar varlığın defter değerine dâhil edilir. Maddi duran varlıkla ilgili yapılan olağan bakım ve onarım giderleri varlığın maliyetine dâhil edilmez.

Vergi uygulamalarımızdan farklı ancak TMS ve BOBi FRS ile uyumlu olarak, KÜMi FRS'de arazi ve binalar, birbirinden ayrılabilir varlıklardır ve söz konusu varlıklar birlikte edinilmiş olsalar bile ayrı olarak finansal tablolara alınırlar (Gücenme Gençoğlu, 2020: 193).

KÜMi FRS Taslağı'nda maddi duran varlıkların takas yoluyla edimine ilişkin bir düzenleme bulunmamaktadır.

\subsection{MSUGT ve Vergi Uygulamalarımızda Maddi Duran Varlıkların Maliyet Değerinin Tespiti}

MSUGT kapsamındaki Tekdüzen Hesap Planında da satın alınan maddi duran varlıklar maliyet değeri ile kayda alınır. Maliyet değerinin tespiti ile ilgili düzenlemeler VUK'da yer almaktadır. Vergi uygulamalarımızda ve Tekdüzen Hesap Planında, arsa ve bina bedelinin ayrımı yapılmaz, arsa ve bina bedeli toplamı binanın maliyet unsuru olarak kayda alınır.

VUK'da duran varlıkların maliyet değerinin tespiti ile ilgili olarak 269 uncu maddesine göre; "iktisadi işletmelere dahil bilumum gayrimenkuller maliyet bedeli ile değerlenir. Duran varlıkların gayrimenkul ve gayrimenkul olarak değerlendirilen iktisadi kıymetlerin değeri maliyet bedelidir. VUK 270. Maddesine göre satın alma yolu ile edinilen duran varlıklarda ayrıca; makine ve tesisatta gümrük vergileri ve bunların nakliye ve montaj giderleri, mevcut bir binanın satın alınarak yıkılması ve arsasının tesviyesine ilişkin olarak yapılan tüm giderlerin, satın alma bedeline eklenmesi zorunludur" (VUK madde 270). Aynı kanun maddesine göre, "gayrimenkul ve gayrimenkul olarak değerlendirilen iktisadi kıymetler için ödenen alış giderleri ve vergilerini, mükellefler ister maliyet bedeline dahil ederler ister doğrudan doğruya genel gider olarak kaydedebilirler." Buna göre standartlarda varlığın edinimi ve kullanılabilir hale getirilmesi ile doğrudan ilgili giderlerin maliyet bedeli içinde yer alması gerektiği halde vergi mevzuatında belirtilen unsurların maliyete ilavesinde ihtiyariliğin bulunması farklılık arz etmektedir. VUK 271 'inci maddesine göre "inşa edilen binalarda ve gemilerde, imal edilen makine ve tesisatta, bunların inşa ve imal giderleri satın alma bedeli yerine geçer."

İ̧letmeler, aktiflerinde yer alan duran varlıklarla ilgili olarak kullandıkları süre içinde birçok harcama yapabilirler. Bu harcamalar, işletme tarafından ya ilgili duran varlığın maliyetine ilave edilebilir ya da dönem gideri olarak yazılabilir. Buna ilişkin VUK 272'nci maddesine göre; "Normal bakım, tamir ve temizleme giderleri 
dışında gayrı menkulü veya elektrik üretim ve dağıtım varlıklarını genişletmek veya iktisadi kıymetlerini devamlı olarak artırmak maksadıyla yapılan giderler, gayrimenkulün veya elektrik üretim ve dağıtım varlıklarının maliyet bedeline eklenir. (Bir geminin iktisap tarihindeki süratini fazlalaştırmak, yolcu ve eşya yükleme ve barındırma tertibatını genişletmek veya değiştirmek suretiyle iktisadi kıymetini devamlı olarak arttıran giderlerle bir motorlu kara nakil vasıtasının veya motorunun yenisi ile değiştirilmesi veya alımında mevcut olmayan yeni bir tertibatın eklenmesi için yapılan giderler maliyet bedeline eklenmesi gereken giderlerdendir)." Bu düzenlemeler genel olarak standartlar ile uyumludur. Özetle yapılan harcama ilgili duran varlığın verimini, hizmet süresini veya değerini artırıyorsa ya da sabit varlığa yeni bir eklemede bulunuluyorsa, söz konusu harcama ilgili duran varlığın maliyetine ilave edilerek aktifleştirilmelidir. Bu tür harcamalar büyük onarım ve büyük parça yenilemeleri, ekleme ve genişletmeler, sabit kıymeti geliştirme ve iyileştirme harcamalarıdır. Eğer yapılan harcama duran varlığı iyi çalışır durumda tutmak üzere yapılan normal bakım ve onarım gideri ise bu durumda dönem gideri olarak kaydedilmelidir. Bu tür harcamalar bozulma, aşınma, çürümeyi önlemek için yapılan silme, temizleme, yağlama, boyama veya sabit kıymetin mevcut ömrünü muhafaza etmek için yapılan onarım ve küçük parça yenilemeleri gibi giderlerden oluşur.

Vergi uygulamalarında, borçlanma maliyetleri, herhangi bir koşula bağlı olmaksızın mükellef tarafından istenirse duran varlık maliyeti içinde yer alabilmektedir. 163 nolu VUK Genel Tebliği'ne göre duran varlıkların edinimi için kullanılan kredilerin faiz giderleri ve kur farklarından, aktifleştirme döneminin sonuna kadar olan kısmının maliyete dahil edilmesi, aktifleştirildiği dönemden sonraki kısmın ise isteğe bağlı olarak aktifleştirilmesi veya doğrudan gider kaydedilmesi mümkündür. 334 nolu VUK Genel Tebliği'nde de kurlardaki azalma nedeniyle işletme lehine ortaya çıkan kur farklarından, aktifleştirme işleminin yapıldığı dönemin sonuna kadar ortaya çıkanlar maliyetle ilişkilendirilir, sonraki dönemlerdekiler ise isteğe bağlı olarak maliyetten düşülebilir veya kambiyo karı olarak kaydedilebilir.

Borçlanma maliyetlerinin duran varlık maliyeti içinde yer alması, TMS ve BOBi FRS'de koşula bağlamış olmasına karşılık, bu standartlardan farklı olarak vergi uygulamalarında kredi faizleri kazanılma döneminin sonuna kadar maliyete eklenmekte, sonra istenirse gider olarak kaydedilmektedir (Yelgen ve Uyar, 2018: 103).

TMS'de vadeli alım işlemlerinin tamamında, BOBi FRS'de ise bir yıldan uzun vadeli alımlarda faiz ayrıştırması yapılarak varlığın elde etme maliyetinin peşin fiyatına eşit olarak belirlenmesi gerektiği halde, KÜMi FRS ve vergi uygulamalarımızda faiz ayrıştırması yapılmaz. KÜMi FRS ve vergi uygulamalarında vade farkı nedeniyle ortaya çıkan faiz ve kur farkı duran varlık maliyeti içinde yer almakta ve bu husus tam set standartlar ile BOBI FRS arasında önemli bir uygulama farklılığına neden olmaktadır.

Vergi uygulamalarımızda takas yoluyla edinimde, verilen varlığın defter değeri, alınan varlığın defter değeri olarak raporlanmaktadır.

\subsection{Maddi Duran Varlıkların illk kaydı ve Maliyet Değerinin Tespitinde Finansal Raporlama Çerçeveleri Arasındaki Farklar}

Yukarıda yapılan açıklamalara göre, maddi duran varlıkların edinimi ve maliyetinin tespitine ilişkin TFRS 16, BOBi FRS, KÜMi FRS Taslağı ve vergi uygulamalarının karşılaştırması Tablo 1'de özetlenmektedir.

Tablo 1. Maddi Duran Varlıkların Illk Kaydı ve Maliyet Değerinin Tespitine iliş̧kin Karşılaştırma

\begin{tabular}{|l|c|c|c|c|}
\hline & TFRS 16 & BOBi FRS & $\begin{array}{c}\text { KÜMi FRS } \\
\text { Taslak }\end{array}$ & $\begin{array}{c}\text { MSUGT } \\
\text { Vergi Uygulamaları }\end{array}$ \\
\hline $\begin{array}{l}\text { Arsa-Bina } \\
\text { Ayırımı }\end{array}$ & $\begin{array}{c}\text { Arsa-binalar ayrı } \\
\text { raporlanır. }\end{array}$ & $\begin{array}{c}\text { Arsa-binalar ayrı } \\
\text { raporlanır. }\end{array}$ & $\begin{array}{c}\text { Arsa-binalar ayrı } \\
\text { raporlanır. }\end{array}$ & $\begin{array}{c}\text { Arsa-bina ayrımı } \\
\text { yapılmaz. }\end{array}$ \\
\hline $\begin{array}{l}\text { Maliyetin } \\
\text { Kapsamı }\end{array}$ & $\begin{array}{c}\text { Alış giderleri } \\
\text { maliyete ilave edilir. }\end{array}$ & TMS ile uyumlu & TMS ile uyumlu & $\begin{array}{c}\text { Genel olarak alış } \\
\text { giderlerinin maliyete } \\
\text { ilavesi ihtiyaridir. }\end{array}$ \\
\hline
\end{tabular}


Tablo 1. Maddi Duran Varlıkların Illk Kaydı ve Maliyet Değerinin Tespitine Illişkin Karşılaştırma (Devam)

\begin{tabular}{|c|c|c|c|c|}
\hline Vadeli Alım & $\begin{array}{l}\text { Tüm vade farkları } \\
\text { ayrıştırılır. }\end{array}$ & $\begin{array}{l}\text { Bir yıldan uzun } \\
\text { vadelerde faiz } \\
\text { ayrıştırılır. }\end{array}$ & $\begin{array}{l}\text { Faiz ayrıştırması } \\
\text { yapılmaz. Maliyet } \\
\text { değerinin içinde } \\
\text { vade farkı da yer } \\
\text { alır. }\end{array}$ & $\begin{array}{l}\text { Faiz ayrıştırması } \\
\text { yapılmaz. Maliyet } \\
\text { değerinin içinde vade } \\
\text { farkı da yer alır. }\end{array}$ \\
\hline $\begin{array}{l}\text { Borçlanma } \\
\text { Maliyetleri }\end{array}$ & $\begin{array}{l}\text { Sadece özellikli } \\
\text { varlıklarda } \\
\text { borçlanma maliyeti } \\
\text { varlık maliyetine } \\
\text { ilave edilir. }\end{array}$ & $\begin{array}{c}\text { Özellikli varlık tanımı } \\
\text { yok. İş̧ası } 1 \text { yıldan } \\
\text { uzun süren MDV } \\
\text { borçlanma maliyeti } \\
\text { varlık maliyetine ilave } \\
\text { edilir. }\end{array}$ & $\begin{array}{c}\text { Oluştukları } \\
\text { dönemde kar } \\
\text { zarara yansıtılır. } \\
\text { Özel durumlardan } \\
\text { söz edilmemiştir. }\end{array}$ & $\begin{array}{c}\text { Koşula bağı } \\
\text { olmaksızın istenirse } \\
\text { duran varlık maliyeti } \\
\text { içinde yer alabilir. }\end{array}$ \\
\hline $\begin{array}{l}\text { Takas Yoluyla } \\
\text { Edinim }\end{array}$ & $\begin{array}{l}\text { Varsa elde edilen, } \\
\text { yoksa elden çıkarılan } \\
\text { varlığın GUD, ya da } \\
\text { elden çıkarılan } \\
\text { varlığın defter değeri } \\
\text { ile ölçülür }\end{array}$ & $\begin{array}{l}\text { Elden çıkarılan varlığın } \\
\text { defter değeri esas alınır, } \\
\text { parasal kalem alınmış } \\
\text { veya verilmiş ise net } \\
\text { defter değerine eklenir } \\
\text { veya çıkartııır. }\end{array}$ & $\begin{array}{l}\text { Düzenleme yer } \\
\text { almamaktadır. }\end{array}$ & $\begin{array}{l}\text { Elden çıkarılan } \\
\text { varlığın defter değeri } \\
\text { esas alınır. }\end{array}$ \\
\hline $\begin{array}{l}\text { Sonraki } \\
\text { Dönemlerde } \\
\text { Yapılan } \\
\text { Harcamalar }\end{array}$ & $\begin{array}{l}\text { Varlıktan beklenen } \\
\text { faydayı artırıyorsa } \\
\text { maliyete ilave edilir. }\end{array}$ & TMS ile uyumlu & $\begin{array}{l}\text { TMS ve BOBi FRS } \\
\text { ile uyumlu }\end{array}$ & Standartlarla uyumlu. \\
\hline
\end{tabular}

\section{Finansal Raporlama Çerçevelerine Göre Sonraki Dönemlerde Maddi Duran Varlıkların Ölçümü}

Bir yıldan uzun süreli kullanımı olan maddi duran varlıklarda, maliyet değerinin yanında raporlama tarihindeki cari değeri ifade eden gerçeğe uygun değerin de hesaplanmasına ve bu değer ile raporlama yapılmasına izin verilmekte, özellikle tam set standartlarda gerçeğe uygun değerin kullanımı teşvik edilmektedir. Maddi duran varlıkların ölçümüne ilişkin açıklamalar her bir raporlama çerçevesi için ayrı ayrı olmak üzere aşağıda "sonraki dönemlerdeki ölçüm" başlığı altında ele alınmıştır.

TMS/TFRS'ye uygun finansal raporlama için Kavramsal Çerçeve'de tarihi maliyet, cari değer, gerçeğe uygun değer, kullanım ve itfa değerleri ölçütlerine yer verilmiş ve detaylı olarak tanımlamaları yapılmıştır. BOBI FRS' de ise gerçeğe uygun değer gibi başka bir ölçüm esası belirlenmediği sürece maliyet esaslı bir ölçüm öngörülmüştür (Karataş Aracı ve Bekçi, 2019: 880). Ancak maddi duran varlıkların sonraki dönemlerdeki ölçümü için, TMS 16, BOBi FRS ve KÜMi FRS Taslağı'nda maliyet ya da yeniden değerleme yönteminin kullanılabileceği belirtilmektedir. Bu iki yöntemi birbirinden ayıran en önemli özellik, maliyet yönteminde sadece gerçekleşmemiş zararların (değer azalışlarının) kayda alınması, gerçekleşmemiş kazançların kayda alınmaması; yeniden değerleme yönteminde ise gerçekleşmemiş kazanç ve kayıpların (değer artış ve azalışlarının) her ikisinin de kayda alınmasıdır. Her üç raporlama çerçevesinde de yöntemlerin uygulanmasına ait düzenlemeler benzerdir ve değer artışları özkaynaklarda raporlanmaktadır. Ancak TMS 16 'ya göre yeniden değerleme yönteminde değer artışı kapsamlı gelir olarak adlandırıır ve hem özkaynaklarda kar zarara aktarılmayacak kapsamlı gelir olarak raporlanır, hem de kar zarar tablosundaki dönem karına ilaveten raporlanarak toplam kapsamlı gelir hesaplanmasını gerektirir. BOBI FRS ve KÜMi FRS Taslağı'nda ise bu değer artışı sadece özkaynaklarda raporlanır, kar zarar tablosuna ilave edilmez ve kapsamlı gelir hesaplanmaz.

MSUGT'da finansal tablo kalemlerine sonraki dönemlere ilişkin ölçümleme ve değerleme hükümleri bulunmadığından maddi duran varlıklar uygulamada genellikle VUK'daki değerleme hükümlerine uygun olarak raporlanmaktadır.

\subsection{TMS 16'ya Göre Sonraki Dönemlerdeki Ölçüm}

TMS 16'ya göre maddi duran varlıkların sonraki dönemlerdeki ölçümünde "maliyet yöntemi veya yeniden değerleme yöntemi olmak üzere iki yöntem kullanılmaktadır." Temel yöntem olarak ifade edilen maliyet yönteminde "maddi duran varlık kalemi ilk muhasebeleştirmeden sonra, söz konusu duran varlık 
kaleminin maliyetinden birikmiş amortisman ve birikmiş değer düşüklüğü zararları indirildikten sonraki tutar ile izlenir. Buna göre her dönemin sonunda maddi duran varlıklar değer düşüklüğü testine tabi tutulur ve değer düşüklüğü varsa bunun için karşılık ayrılarak gider kaydı yapılır." Ertesi dönemlerde varlığın değeri artarsa, bu artış, aynı varlığın daha önce gider olarak kaydedilen değer azalışını tersine çevirdiği ölçüde gelir kaydedilir. Ancak varlığın değeri maliyet değerini aşamaz.

Alternatif yöntem olarak isimlendirilen yeniden değerleme yönteminde ise, "gerçeğe uygun değeri güvenilir olarak ölçülebilen bir maddi duran varlık kalemi, varlık olarak muhasebeleştirildikten sonra, bilançoda yeniden değerlenmiş tutarı ile raporlanır. Buna göre maddi duran varlıklardaki hem değer artışlarının hem de değer azalışlarının kaydı yapılmalıdır. Yeniden değerlenmiş tutar, yeniden değerleme tarihindeki gerçeğe uygun değerinden, gerçeğe uygun değer üzerinden hesaplanan birikmiş amortisman ve gerçeğe uygun değer üzerinden hesaplanan birikmiş değer düşüklüğü zararının indirilmesi suretiyle bulunan değerdir."

TMS 16'ya göre maddi duran varlık kalemlerinin gerçeğe uygun değeri piyasa değerleridir. TMS 36'nın 6'ncı maddesine göre gerçeğe uygun değer "piyasa katılımcıları arasında ölçüm tarihinde olağan bir işlemde, bir varlığın satışından elde edilecek veya bir borcun devrinde ödenecek fiyat" olarak tanımlanmıştır. "Bir varlığın defter değerinin geri kazanılabilir tutarını aşmış olması durumunda, ilgili varlık değer düşüklügüne uğramıştır. Geri kazanılabilir değer, bir varlığın net satış fiyatı ve kullanım değerinden büyük olanıdır. Kullanım değeri, bir varlığın sürekli kullanımından ve faydalı ömrü sonunda elden çıkarılmasından elde edilmesi beklenen nakit akımlarının tahmin edilen bugünkü değeridir. Bunun tespiti için, varlığın sürekli kullanımı ve elden çıkarılmasından kaynaklanan nakit giriş ve çıkışlarının tahmini ve bu nakit akımlarını iskonto etmekte kullanılacak uygun iskonto oranının tespiti gerekir. Gelecekteki nakit akımları, üretileceği yabancı para cinsinden tahmin ediliyorsa, o yabancı paraya uygun olan iskonto oranı kullanılarak şimdiki değere indirgenir ve bilanço tarihindeki kur üzerinden çevrilir."

"Eğer bir varlığın defter değeri yeniden değerleme sonucunda artmışsa, bu artış diğer kapsamlı gelirde muhasebeleştirilmelidir ve doğrudan özkaynak hesap grubunda yeniden değerleme değer artışı adı altında toplanmalıdır. Ancak, bir yeniden değerleme değer artışı, aynı varlığın daha önce kar ya da zarar ile ilişkilendirilmiş bulunan yeniden değerleme değer azalışını tersine çevirdiği ölçüde gelir olarak muhasebeleştirilir" (TMS 16 madde 39).

TMS 16'ya göre, "diğer kapsamlı gelirler, özkaynaklarda artışa neden olan sermaye ve kâr yedeği niteliğindeki kâr ya da zararda muhasebeleştirilmeyen gelir ve gider (yeniden sınıflandırma düzeltmeleri de dâhil olmak üzere) kalemlerini kapsamaktadır ve bunların gelir tablosunda da raporlanması gerekmektedir."

Financial Accounting Standards Board (FASB), 1985 yılında yayınladığı standarda göre kapsamlı gelir "işletmenin belirli faaliyet dönemi boyunca ortaklarının sağladığı kaynaklar haricindeki özkaynak değişimleri" olarak tanımlamıştır (FASB bölüm 70).

Kılıç (2019)'a göre, "işletmelerin kapsamlı gelir raporlama uygulamalarını dokuz yıllık bir süreç içinde incelediği çalışmasında, diğer kapsamlı gelir unsurlarının işletmelerin dönem net kârını zarara, dönem net zararını kâra dönüştürdüğü gözlem sayısının oldukça düşük olduğunu" ifade etmektedir. Buna göre, "diğer kapsamlı gelir unsurlarının dönem net kârı (zararı) değerinin yönü üzerindeki etkisi son derece kısıtıdır. Ayrıca, yıllara göre değişkenlik gösterse de diğer kapsamlı gelir unsurları dönem net kârı üzerinde çoğunlukla pozitif bir etki göstermekte ve toplam kapsamlı gelir daha yüksek bir tutar olarak ortaya çıkmaktadır."

"Eğer bir varlığın defter değeri yeniden değerleme sonucunda azalmışsa, bu azalma gider olarak muhasebeleștirilir. Ancak, bu azalış diğer kapsamlı gelirde bu varlıkla ilgili olarak yeniden değerleme fazlasındaki her tür alacak bakiyesinin kapsamı ölçüsünde muhasebeleştirilmelidir. Diğer kapsamlı gelirde muhasebeleştirilen söz konusu azalış, yeniden değerleme fazlası başlığı altında özkaynaklarda birikmiş olan tutarı azaltır" (TMS 16 madde 40).

"Bir maddi duran varlık kalemine ilişkin özkaynak hesap grubundaki yeniden değerleme değer artışı, ilgili varlık finansal tablo dışı bırakıldığında doğrudan geçmiş yıl kârlarına aktarılabilir." Aynı husus varlığın kullanımdan çekilmesi veya elden çıkarılması durumunda da geçerli olabilir. Öte yandan, "değer artışının bir 
kısmı, varlık işletme tarafından kullanıldıkça da aktarılabilir. Bu durumda, aktarılan değer artışı, varlığın yeniden değerlenmiş defter değeri üzerinden hesaplanan amortisman ile orijinal maliyeti üzerinden hesaplanan amortisman arasındaki fark kadar olur. Yeniden değerleme değer artışından geçmiş yıl kârlarına aktarım kâr veya zarar üzerinden yapılamaz" (TMS 16 madde 41). Özkaynaklardaki değer artış hesabının sermayeye aktarılarak sermaye artırımı için kullanılması da tüm finansal raporlama çerçeveleri için mümkündür.

\subsection{BOBi FRS'ye Göre Sonraki Dönemlerdeki Ölçüm}

Maddi duran varlıkların sonraki dönemlerde ölçümü için TMS 16'da kullanılan maliyet ve yeniden değerleme yöntemi aynı ilkeler paralelinde BOBi FRS'de de kullanılmaktadır. Ancak TMS 16'dan farklı olarak, değer artışı özkaynaklarda kapsamlı gelir adıyla raporlanmaz ve kar veya zarar tablosuna taşınmaz. ВОВi FRS'de kapsamlı kar hesaplanmadığından, değer artışı sadece finansal durum tablosunda özkaynaklarda "Yeniden Değerleme Yedeği" kaleminde gösterilir. Eğer önceden varlık için değer düşüklüğü karşılığı ayrılarak gider kaydedilmişse, değer artışı için önce karşılık iptal edilir ve gelir kaydı yapılır, kalan kısım özkaynaklarda raporlanır. illgili varlık satıldığında değer artışı, TMS 16 'da olduğu gibi dönem karı ile ilişkilendirilmez, geçmiş yıllar karına aktarıır. BOBi FRS'de varlı̆ın kullanım süresi içinde yeniden değerlemeden önceki ve sonraki yıllık amortisman paylarının geçmiş yıllar karından mahsubuna ilişkin bir düzenleme bulunmamaktadır.

Sonraki dönemlerde maddi duran varlıklarda, BOBi FRS Bölüm 18'e göre hesaplanan değer azalışı, maliyet yönteminde doğrudan gider kaydedilir ve kar zarar tablosunda raporlanır. Eğer yeniden değerleme yöntemi kullanılıyorsa ve varlık ile ilgili özkaynaklarda kayıtlanmış bir değer artış fonu varsa, değer azalışı önce bu fondan düşülür, kalan kısım gider olarak kar veya zarar tablosunda raporlanır. BOBi FRS Bölüm 18'e göre, "bir varlığın defter değerinin geri kazanılabilir tutarından büyük olması durumunda değer düşüklüğü zararı oluşur. Geri kazanılabilir tutar, varlığın (veya nakit yaratan birimin) satış maliyetleri düşülmüş gerçeğe uygun değeri ile kullanım değerinden yüksek olanıdır. Bir varlığın kullanım değerinin, satış maliyetleri düşülmüş gerçeğe uygun değerini önemli ölçüde aşmayacağı değerlendiriliyorsa, varlığın satış maliyetleri düşülmüş gerçeğe uygun değeri geri kazanılabilir tutar olarak kullanılabilir."

\subsection{KÜMi FRS Taslağı'na Göre Sonraki Dönemlerdeki Ölçüm}

KÜMi FRS' de, BOBI FRS ile uyumlu olarak, maddi duran varlıklar için, maliyet ya da yeniden değerleme yönteminin kullanılabileceği" belirtilmektedir. "Yeniden değerlenmiş tutar, yeniden değerlemenin yapıldığı tarihteki gerçeğe uygun değerdir. Bu tarihten sonra varlığın yeniden değerlenmiş tutarı; varlığın yeniden değerlendiği tarihteki gerçeğe uygun değerinden, yeniden değerlemenin yapıldığı tarihten sonraki birikmiş amortisman tutarı ve birikmiş değer düşüklüğü zararı indirilerek hesaplanır. Yeniden değerleme tarihindeki gerçeğe uygun değeri, ilgili maddi duran varlığın değerlemesini yapmak üzere kamu kurumlarınca yetkilendirilmiş kişiler tarafından belirlenebileceği gibi gerekli mesleki bilgiye sahip ve maddi duran varlığın sınıf ve yeri hakkında güncel bilgisi bulunan kişiler tarafından da belirlenebilir."

Yeniden değerleme yöntemi kullanılıyorsa, BOBi FRS'de olduğu gibi, değer artışları finansal durum tablosunda özkaynaklarda "Yeniden Değerleme Değer Artışları" kaleminde raporlanır. Eğer aynı varlığın daha önce gider kaydedilen değer azalışı varsa, önce bunun iptali için gelir kaydı yapılır. Bir maddi duran varlık finansal tablo dışı bırakıldığında, bu varlığa ilişkin olarak "Yeniden Değerleme Değer Artışları" kaleminde yer alan birikmiş tutar "Geçmiş Yıllar Kârları/Zararları" kalemine aktarılır.

Yeniden değerleme yönteminde, maddi duran varlıklardaki değer azalışları, varsa önce aynı varlık için özkaynaklardaki "Yeniden Değerleme Değer Artışları" kaleminde yer alan tutardan indirilir, kalan tutar kar zarar tablosunda varlığın kullanıldığı yere göre ilgili fonksiyonel gider hesabına kaydedilir. Değer azalışları, KÜMi FRS bölüm 16 "Varlıklarda Değer Düşüklüğü" hükümlerine göre hesaplanmaktadır. Buna göre geri kazanılabilir değer hesaplanırken net satış değeri esas alınır. TMS 16 ve BOBi FRS'deki kullanım değeri kavramına burada yer verilmemiştir. KÜMi FRS'ye göre, "her raporlama dönemi sonunda varlığın defter değeri ile satış maliyetleri düşülmüş gerçeğe uygun değeri karşılaştırılır." BOBi FRS'den farklı olarak KÜMi FRS Bölüm 16, 8 inci maddesinde "Varlığın satış maliyetleri düşülmüş gerçeğe uygun değerinin, defter değerinden 
\%10 veya daha fazla düşük olması durumunda varlıklara ilişkin değer düşüklüğü zararları kâr veya zarara yansıtılır" hükmü yer almaktadır.

Maliyet yöntemi uygulandığında, TMS 16 ve ВОВі FRS'de olduğu gibi, "her raporlama dönemi sonunda maddi duran varlık kalemlerindeki değer düşüklügü zararının finansal durum tablosunun aktifinde eksi olarak ve kar veya zarar tablosunda da gider olarak raporlanır." Sonraki dönemlerde "varlığın geri kazanılabilir tutarının defter değerini aşması durumunda, ilgili varlığa ilişkin değer düşüklügü̈ zararının tamamı ya da bir kısmı iptal edilir. Değer düşüklüğü zararının iptal edilecek kısmı, ilgili varlığa ilişkin önceki dönemlerde değer düşüklüğü zararı finansal tablolara alınmamış olsaydı varlığın ulaşacağı (amortisman veya itfa payı çıkarılmış olarak) defter değeri esas alınarak belirlenir. Değer düşüklüğü zararının iptalinden sonra varlığın yeni defter değeri bu değeri aşamaz" (KÜMi FRS bölüm 16 madde 13).

Bir maddi duran varlık finansal tablo dışı bırakıldığında, bu varlığa ilişkin olarak "Yeniden Değerleme Değer Artışları" kaleminde yer alan birikmiş tutar "Geçmiş Yıllar Kârları/Zararları" kalemine aktarılır."

\subsection{MSUGT ve Vergi Uygulamalarında Sonraki Dönemlerdeki Ölçüm}

Maddi duran varlıkların ediniminden sonraki dönemlerde ortaya çıkan değer artış (azalışlarının) raporlanması ile ilgili Vergi Usul Kanunu’nda önceki yıllarda yer alan ve yeniden değerleme katsayısı ile varlık maliyet değerinin çarpımı ile gerçekleştirilen yeniden değerleme uygulaması, 17/12/2003 tarihinde, Mükerrer Madde 298 kapsamındaki enflasyon düzeltmesinin getirilmesi ile kaldırılmıştır. Getirilen madde hükmüne göre, kazançlarını bilanço esasına göre tespit eden, gelir ve kurumlar vergisi mükellefleri fiyat endeksindeki artışın içinde bulunulan dönem dahil, son üç hesap döneminde $\% 100$ 'den ve içinde bulunulan hesap döneminde $\% 10$ 'dan fazlası olması halinde mali tablolarını enflasyon düzeltmesine tabi tutarlar. 05.05.2004 tarihli 12 sıra nolu Muhasebe Sistemi Uygulama Genel Tebliği ile enflasyon düzeltmesinin kayıtlanması için Tekdüzen Hesap Planı'na "502. Sermaye Düzeltmesi Olumlu Farkları" ve "503. Sermaye Düzeltmesi Olumsuz Farkları" ilave edilmiştir. Ülkemizde bu düzenlemeye göre enflasyon düzeltmesi 2003 yılını takiben 2004 yılında birkaç ara dönem dışında, koşullar gerçeklemediği için uygulanmamıştır. Zaten enflasyon düzeltmesi standartlarda yer alan "ölçüm" ya da VUK'daki değerleme karşılığı değildir. Enflasyon düzeltmesi dışında vergi yasalarımızda maddi duran varlıkların ediniminden sonraki dönemlerde değer artış ve azalışlarının tespitine yönelik bir düzenleme bulunmamaktadır. MSUGT kapsamında da, standartlardaki düzenlemelere uygun olarak MDV'larda sonraki dönemlerde ortaya çıkan değer artış/azalışlarının raporlanmasını sağlayan hesaplar yer almamaktadır. Tekdüzen Hesap Planı’nda yer alan "522 Maddi Duran Varlık Değerleme Artışları" hesabı, 2003 öncesi Vergi Usul Kanunu’nda yer alan ve sadece maddi duran varlıklar için kullanılan, maddi duran varlık defter değeri ile Devlet tarafından açıklanan yeniden değerleme katsayısının çarpımı ile bulunan değer artışının kaydı ve raporlanması fonksiyonunu yerine getirmiştir. 2003 yılında bu madde hükmünün, enflasyon düzeltmesine dönüştürülmesi ile hesap fonksiyonunu kaybetmiş ve genel olarak kullanılmamıştır. Zaten Tekdüzen Hesap Planı'ndaki bu hesaba ait açıklamalar standartların gereklerini karşılama niteliğine sahip değildir, standartlardaki yeniden ölçüm tanımını karşılamamaktadır. Örneğin standartlarda yeniden değerleme artışlarının kaydedildiği özkaynak hesabı, ilgili varlık satıldığında geçmiş yıllar karına aktarıldığı halde, 522 nolu hesap için böyle bir düzenleme bulunmamaktadır.

Öte yandan Tekdüzen Hesap Planı'nda sadece amortisman yoluyla maddi duran varlıklardaki değer kayıpları aktifte eksi olarak raporlanmaktadır. Standartlara göre eğer yıllık amortisman payı ile karşılanmayan değer azalışları varsa, bu değer azalışlarının ilgili varlığın aktifteki değerinden düşülmesi gerekir. Standartlara göre değer azalışı, aktifte ve aşağıda açıklandığı gibi önceden bir fon varsa pasifte eksi olarak raporlanmalıdır. Vergi uygulamalarımızda böyle bir değer azalışının tespitine yönelik düzenleme bulunmamakta, Tekdüzen Hesap Planı́nda değer azalışı için kullanılacak bir düzenleyici hesap yer almamaktadır.

\subsection{Maddi Duran Varlıkların Sonraki Dönemlerdeki Ölçümünde Finansal Raporlama Çerçeveleri Arasındaki Farklar}

Maddi duran varlıkların sonraki dönemlerdeki ölçümünde finansal raporlama çerçeveleri arasındaki önceki başlıklarda belirtilen farklar Tablo 2'de özetlenmiştir. 
Tablo 2. Maddi Duran Varlıkların Sonraki Dönemlerde Ölçümüne İlişkin Karşılaştırma

\begin{tabular}{|c|c|c|c|c|}
\hline & TFRS 16 & ВOBİ FRS & $\begin{array}{l}\text { KÜMi FRS } \\
\text { Taslak }\end{array}$ & $\begin{array}{c}\text { MSUGT } \\
\text { Vergi Uygulamaları }\end{array}$ \\
\hline $\begin{array}{l}\text { Sonraki Ölçüm } \\
\text { Yöntemi }\end{array}$ & $\begin{array}{c}\text { Maliyet değeri veya } \\
\text { yeniden değerleme } \\
\text { yöntemi }\end{array}$ & TFRS ile uyumlu & TFRS ile uyumlu & $\begin{array}{c}\text { Sadece maliyet } \\
\text { yöntemi }\end{array}$ \\
\hline Değer Artışı & $\begin{array}{l}\text { Kapsamlı gelir olarak } \\
\text { raporlanır. }\end{array}$ & $\begin{array}{l}\text { Kapsamlı gelir } \\
\text { yok. Özkaynak } \\
\text { kalemi olarak } \\
\text { raporlanır. }\end{array}$ & $\begin{array}{c}\text { Kapsamlı gelir yok. } \\
\text { Özkaynak kalemi } \\
\text { olarak raporlanır. }\end{array}$ & $\begin{array}{l}\text { Değer artışı } \\
\text { hesaplanmaz ve } \\
\text { raporlanmaz. }\end{array}$ \\
\hline $\begin{array}{l}\text { Değer Artışı } \\
\text { Hesabının } \\
\text { Geçmiş Yıllara } \\
\text { Aktarılması }\end{array}$ & $\begin{array}{c}\text {-Varlık satıldığında, } \\
\text { kullanımdan çekildiğinde, } \\
\text { - Yeniden değerlemeden } \\
\text { sonraki ve önceki yıllık } \\
\text { amortisman payı arasındaki } \\
\text { fark }\end{array}$ & $\begin{array}{l}\text { Varlık } \\
\text { satıldığında, } \\
\text { kullanımdan } \\
\text { çekildiğinde }\end{array}$ & $\begin{array}{l}\text { Varlık satıldığında, } \\
\text { kullanımdan } \\
\text { çekildiğinde }\end{array}$ & Düzenleme yok \\
\hline $\begin{array}{l}\text { Değer } \\
\text { Azalışlarının } \\
\text { Hesaplanması }\end{array}$ & $\begin{array}{c}\text { Geri kazanılabilir değer < } \\
\text { defter değeri }\end{array}$ & TFRS ile uyumlu & $\begin{array}{l}\text { Net satış değeri< } \\
\text { defter değeri } \\
\text { Kullanım değeri } \\
\text { kavramı yok. }\end{array}$ & $\begin{array}{l}\text { Değer azalışı } \\
\text { hesaplanmaz. }\end{array}$ \\
\hline $\begin{array}{l}\text { Değer Azalışının } \\
\text { Raporlanması }\end{array}$ & $\begin{array}{l}\text { Maliyet yönteminde gider } \\
\text { kaydedilir. Yeniden } \\
\text { değerlenme fonu varsa } \\
\text { önce bundan düşülür kalan } \\
\text { gider kaydedilir. }\end{array}$ & TFRS ile uyumlu & TFRS ile uyumlu & $\begin{array}{l}\text { Değer azalışı } \\
\text { raporlanmaz. }\end{array}$ \\
\hline
\end{tabular}

\section{Finansal Raporlama Çerçevelerine Göre Maddi Duran Varlıklarda Amortismanların Hesaplanması ve Raporlanması}

Bilindiği gibi amortisman, "duran varlıklarda kullanımdan, belli bir sürenin geçmesinden ve teknolojik gelişmeler nedeniyle varlığın demode olmasından dolayı ortaya çıkabilecek eskime, yıpranma ve tükenme şeklindeki değer kayıplarını dikkate alarak, duran varlıkların faydalı ömürlerinin tahmin edilmesi ve bu süre içerisinde söz konusu varlıkların elde etme maliyetlerini gider olarak kayıtlanması ve raporlanmasıdır." Amortismanların raporlaması ile ilgili standartlar ve MSUGT arasında farklılık olmamasına rağmen amortismanların hesaplanması ile ilgili standartlar ile vergi uygulamalarımız arasında önemli farklılıklar bulunmaktadır.

Standartlardaki düzenlemelere göre şekillenen finansal raporlama çerçevelerindeki amortisman uygulamaları genellikle ortak özelliklere sahiptir. Bu nedenle aşağıda tüm standartlara göre amortisman uygulamaları ile vergi düzenlemelerine göre amortisman uygulamaları arasındaki farklar açıklanıp karşılaştırılmaktadır.

Standartlara göre yeniden değerleme yöntemi kullanıldı̆̆ında, "amortisman yeniden değerlemeden sonraki tutar üzerinden ayrılmaktadır." Maddi duran varlık maliyetlerinin hesaplanmasındaki farklılıklar ve borçlanma maliyetlerinin varlık maliyetine yüklenmesi ve vadeli satışlarda faiz ayrıştırması uygulanmasındaki farklılıklar nedeniyle amortismana tabi tutar, vergi uygulamalarındaki amortismana tabi tutar ile aynı olmamaktadır.

Standartlarda amortismana tabi tutar, maddi duran varlığın maliyet bedelinden kalıntı değerin indirilmesi suretiyle belirlenir. Kalıntı değerin önemsiz olması durumunda amortismana tabi tutarın belirlenmesinde dikkate alınmaz. VUK'da kalıntı değer ile ilgili bir düzenleme bulunmamakta ve mevcut uygulamalarda amortisman payları hesaplanırken kalıntı değer dikkate alınmamaktadır.

TMS 16, BOBi FRS ve KÜMi FRS Taslağı'nda maddi duran varlıklar için amortisman ayrılması zorunludur. Amortisman uygulanmasına, "varlık kullanıma hazır olduğunda başlanır, kullanılan gün esasına göre kıst amortisman hesaplanır ve varlığın finansal tablo dışı bırakılmasıyla amortisman işlemine son verilir. 
Amortismana tabi tutar, maddi duran varlığın maliyet bedelinden ya da yeniden değerleme sonrası bulunan tutarından kalıntı değerin indirilmesi suretiyle belirlenir. Amortisman yöntemi, varlığın gelecekteki ekonomik faydasının işletme tarafından öngörülen tüketim şeklini yansıtacak şekilde tespit edilir." Doğrusal yöntem, azalan bakiyeler yöntemi ve üretim miktarı yöntemleri gibi yöntemler kullanılabilir. "Amortisman ayırma işlemine, varlık atıl bırakıldı̆̆ında ya da kullanımdan kaldııldığında da devam edilir. Amortisman giderleri, başka bir varlığın defter değerine dâhil edilmediği sürece, kar veya zarar tablosunda, ilgili varlığın kullanıldığı işletme fonksiyonlarına ilişkin giderlerin raporlandığı kalemlerde gösterilir." Vergi uygulamalarımızda amortisman ayırmanın zorunlu olduğuna dair bir hüküm bulunmamaktadır. VUK 320 maddesine göre, "Her yılın amortismanı ancak o yıla ait değerlemede nazara alınabilir. Amortismanın herhangi bir yıl yapılmamasından veya ilk uygulanan nispetten düşük bir hadle yapılmasından dolayı amortisman süresi uzatılamaz."

Standartların amacı, işletmelerin gerçek durumu ortaya koymak olduğu için amortisman ayırmama gibi bir durum söz konusu değildir. VUK'a göre ise amortisman ayırma mükellefin isteğine bırakılmıştır, mükellefler isterlerse amortisman ayırabilirler fakat geçmiş dönemler için ayırmadıkları amortismanları gelecekteki dönemlerde de ayıramazlar, geçmiş dönemler için düzeltme yapamazlar. Vergi uygulamalarında amortisman uygulanması varlığın satın alındığı dönem başlanır, sadece binek otomobilleri için kıst amortisman uygulanır. Bunun dışında varlık dönem içinde hangi tarihte alınmış olursa olsun, dönem için amortisman payı 12 ay üzerinden hesaplanır. VUK'a göre normal koşullarda uygulanabilen amortisman yöntemleri, normal amortisman yöntemi ve azalan bakiyelerle amortisman yöntemi ile sınırlandırılmıştır. Ancak VUK 317'nci maddesine göre; "Yangın, deprem, su basması sonucu değerini tamamen veya kısmen kaybeden, yeni icatlar nedeniyle teknik verim ve kıymetleri tamamen veya kısmen düşerek kullanılmaz hale gelen, cebri çalışmaya tabi tutuldukları için normalden fazla aşınma ve yıpranmaya maruz kalan, sabit kıymetler mükelleflerin müracaatı üzerine ve ilgili bakanlığın mütalaası alınarak Maliye Bakanlığı'nca her işletme için, işin mahiyetine göre ayrı ayrı belirlenen fevkalade ekonomik ve teknik amortisman nispetleri uygulanır." ifadesi yer alır. Ayrıca VUK $316^{\prime} \mathrm{ncI}$ maddesine göre; "Iş̧letme sebebiyle içindeki cevherin azalmasından dolayı maddi değerini kaybeden madenlerin ve taş ocaklarının imtiyaz veya maliyet bedelleri ilgililerin müracaatları üzerine bunların büyüklük ve mahiyetleri göz önünde tutularak her maden veya taş ocağı için ayrı ayrı Maliye Bakanlığı'nca belirlenen nispetler üzerinden yok edilir." Amortisman payları standartlardaki gibi, ilgili varlı̆ıın kullanıldığı işletme fonksiyonlarına ilişkin gider hesaplarına kaydedilir.

Standartlara göre, "faydalı ömür, işletme tarafından gerçekçi tahminlere dayanılarak belirlenir." Amortisman yöntemi, maddi duran varlıktan elde edilecek "gelecekteki ekonomik faydaların beklenen tüketim biçiminde bir değişiklik olmadıkça, seçilen yöntem dönemler itibarıla tutarlı olarak uygulanır." Varlı̆̆ın kullanım şekli değiştiğinde, beklenmeyen ölçüde aşınma veya yıpranma meydana geldiğinde, teknolojik gelişmeler olduğunda, piyasa fiyatlarında değişiklikler meydana geldiğinde veya benzeri durumlarda varlığın kalıntı değeri veya faydalı ömrü değişebilir. Bu tür göstergelerin mevcut olması durumunda faydalı ömre, kalıntı değere ve amortisman yöntemine ilişkin önceki tahminler gözden geçirilir; beklentilerde farklııklar olması durumunda kalıntı değerde, faydalı ömürde ve amortisman yönteminde değişikliklere gidilir. Bu değişiklikler "Muhasebe Politikaları, Tahminler ve Hatalar" uyarınca muhasebe tahminlerindeki değişiklikler olarak nitelendirilir.

Vergi mevzuatına göre ise, mükellefler, amortismana tabi iktisadi kıymetlerini Maliye Bakanlığı'nın her iktisadi kıymet için tespit ve ilan ettiği ekonomik ömür sürelerine göre hesapladıkları oran üzerinden amorti eder. Amortisman yönteminin değiştirilmesi hususunda sadece azalan bakiyeler yönteminden normal amortisman yöntemine geçiş için izin verilmektedir. Bunun dışında varlığın faydalı ömrünün, amortisman yönteminin değiştirilmesi mümkün değildir.

Standartlara göre, "bir maddi duran varlığın önemli bir parçası, maddi duran varlıktan farklı bir faydalı ömre sahip olabilir ve/veya bu parça için maddi duran varlık için kullanılan amortisman yönteminden farklı bir amortisman yöntemi kullanılması gerekli olabilir." Bu durumda bu tür önemli parçalar ayrı bir şekilde amortismana tâbi tutulur. Vergi uygulamalarımızda bu hususta bir düzenleme bulunmamaktadır. 
Tablo 2. Amortisman Uygulamalarına İlişkin Iliş̧kin Karşılaştırma

\begin{tabular}{|c|c|c|}
\hline & $\begin{array}{l}\text { TFRS 16, BOBI FRS, KÜMi FRS } \\
\text { Taslak }\end{array}$ & $\begin{array}{c}\text { MSUGT } \\
\text { Vergi Uygulamaları }\end{array}$ \\
\hline Amortisman Ayrılması & Zorunlu & İhtiyari \\
\hline Faydalı Ömür & $\begin{array}{l}\text { İşletme tarafından gerçekçi tahminlere } \\
\text { göre belirlenir. } \\
\text { Beklentilerde farklılıklar varsa işletme } \\
\text { tarafından değiştirilebilir. }\end{array}$ & $\begin{array}{l}\text { Maliye Bakanlığı tarafından } \\
\text { belirlenir değiştirilemez. }\end{array}$ \\
\hline Amortismana Tabi Tutar & Maliyet değeri -(varsa) Kalıntı değeri & Kalıntı değer dikkate alınmaz. \\
\hline Amortisman Yöntemleri & $\begin{array}{l}\text { Normal amortisman yöntemi azalan } \\
\text { bakiyelerle amortisman üretim birimleri } \\
\text { yöntemi vb. çeşitli yöntemler kullanılabilir. }\end{array}$ & $\begin{array}{c}\text { Normal amortisman yöntemi } \\
\text { azalan bakiyelerle amortisman } \\
\text { yöntemi dışında özel durumlar için } \\
\text { fevkalade amortisman ve } \\
\text { madenlerde amortisman }\end{array}$ \\
\hline $\begin{array}{l}\text { Amortisman } \\
\text { Yöntemlerinde Revizyon }\end{array}$ & $\begin{array}{c}\text { Beklentilerde farklılıklar varsa işletme } \\
\text { tarafından amortisman yöntemi } \\
\text { değiştirilebilir. }\end{array}$ & $\begin{array}{c}\text { Normal amortisman yönteminden } \\
\text { dönülemez. Azalan bakiyeler } \\
\text { yönteminden normal amortisman } \\
\text { yöntemine dönülebilir. }\end{array}$ \\
\hline Kıst Amortisman & Her zaman kıst amortisman uygulanır. & $\begin{array}{c}\text { Sadece binek otomobilleri için kıst } \\
\text { amortisman uygulanır. }\end{array}$ \\
\hline
\end{tabular}

\section{Sonuç}

Maddi duran varlıklar bilançonun aktifinde önemli bir paya sahiptir ve bunlara ilişkin maliyetlerin, değerlemelerin, amortismanların doğru bir şekilde hesaplanması, finansal tabloların doğru bilgi vermesi açısından son derece önem arz etmektedir. TMS, BOBI FRS ve KÜMi FRS Taslağı çerçevesinde maddi duran varlıkların sonraki ölçüm ve amortisman konularında uyumlu olduğu, borçlanma maliyetleri ve vade farklarını uygulama noktasında TMS'den farklı olduğu görülmektedir. BOBi FRS'ye göre bir yıldan kısa vadeli alımlarda, KÜMi FRS Taslağı'nda ise tüm alımlarda vade farkları varlığın maliyetine eklenirken, TMS'ye göre vade farkları varlığın maliyetinden ayrıştııılmaktadır. Ayrıca TMS uygulamasında kapsamlı gelirin raporlanması, finansal tablo kullanıcılarının işletmenin kontrolünde olmayan riskleri de, performans değerlemesi yaparken göz önünde bulundurmalarını ve daha doğru kararlar almalarını sağlamaktadır. Öte yandan kapsamlı gelir raporlamasını eleştirenler, kapsamlı gelir unsurlarının geleneksel dönem kârına eklenmesinin karışıklığa neden olduğunu ve kapsamlı gelir unsurlarının ayrı tablo formatında geleneksel gelir tablosuna ek olarak sunulması gerektiğini savunmaktadırlar.

Gerçeğe uygun değerin tespiti konusundaki düzenlemeler TMS/TFRS'lerde ayrıntılı olarak ele alınmış olmasına karşılık BOBi FRS ve KÜMi FRS Taslağı'nda gerçeğe uygun değerin tespiti için daha sade düzenlemeler yapılmıştır. BOBI FRS'de aynı muhasebe standartlarına uyması beklenen büyük ve orta büyüklükteki işletmeler arasında farklııkların olması nedeniyle, özellikle orta büyüklükteki işletmelerin sunduğu finansal tabloların finansal bilgi kullanıcıları açısından istenen bilgi ihtiyacını karşılayamamasına sebep olabileceği öngörülmektedir. Ancak aynı bakış açısına sahip olan tüm finansal raporlama çerçevelerinin, vergi muhasebesi anlayışının yaygın olduğu ülkemizde, bilgi için raporlama anlayışının yerleşmesinde önemli katkı sağlayacağı tartışmasızdır.

Ülkemizdeki vergi uygulamaları, özellikle sonraki dönemlerdeki ölçüm ve amortismanlar konusunda standartlardaki düzenlemelerden oldukça farklıdır. Devletin vergi alacağını korumak amacıyla yapılan vergi düzenlemelerinin, işletmenin diğer ilgili tarafların ihtiyaçlarını karşılamak ve güvenilir bilgi sunmak amacıyla finansal tablo düzenlenmesini sağlayan standart düzenlemelerinden farklı olması kaçınılmazdır. Standartlar ile vergi düzenlemelerinin işletmeye bakış açısı farklı olduğundan, kapsamındaki düzenlemelerin örtüşmesi de beklenemez. Muhasebenin sosyal sorumluluğu gereği esas olan, standartların gereklerine göre kayıtlama 
ve raporlama ile gerçek faaliyet sonucunun elde edilmesidir. Bu şekilde tespit edilen ticari kardan vergi matrahının hesaplanması tüm ülkelerde olduğu gibi ülkemizde de mükelleflerin kendi sorumluluğundadır.

\section{Beyan ve Açıklamalar (Disclosure Statements)}

1. Bu çalışmanın yazarları, araştırma ve yayın etiği ilkelerine uyduklarını kabul etmektedirler (The authors of this article confirm that their work complies with the principles of research and publication ethics).

2. Yazarlar tarafından herhangi bir çıkar çatışması beyan edilmemiştir (No potential conflict of interest was reported by the authors).

3. Bu çalışma, intihal tarama programı kullanılarak intihal taramasından geçirilmiştir (This article was screened for potential plagiarism using a plagiarism screening program).

\section{Kaynaklar}

Ataman, B., \& Cavlak, H. (2017). Büyük ve Orta Boy Işletmeler İçin Finansal Raporlama Standardı (BOBi FRS) ile Tam Set Türkiye Muhasebe ve Türkiye Finansal Raporlama Standartlarının (TMS/TFRS) karşılaştııılması. Finans Ekonomi ve Sosyal Araştırmalar Dergisi, (2),3, 153-168.

FASB (Financial Accounting Standards Board), (1985). Statement of Financial Accounting Concepts No. 6: Elements of Financial Statements. http://www.fasb.org/resources/ccurl/792/293/CON6.pdf (Erişim Tarihi: 3 Nisan 2020).

Gücenme Gençoğlu, Ü. (2015). Türkiye muhasebe standartları ve vergi mevzuatına göre dönem sonu muhasebe işlemleri. Bursa: Aktüel Yayınları Alfa Kitapevi.

Gücenme Gençoğlu, Ü. (2017). Temel konularda BOBi FRS ve TMS/TFRS karşılaştırması. Muhasebe ve Finansman Dergisi, $76,1-24$.

Gücenme Gençoğlu, Ü. (2020). Küçük ve Mikro İşletmeler İçin Finansal Raporlama Standardı Taslağı'nın BOBi FRS ve vergi uygulamalarımız ile karşılaştırılması ve genel değerlendirme. Business and Economics Research Journal, 11(1), 187-199.

Gücenme Gençoğlu, Ü. (2020). Türkiye'de finansal raporlama standartları ve finansal raporlama çerçeveleri hakkında genel bilgiler. Finansal raporlama standartlarına uygun hesap planı uygulamaları (ss.1-8). Bursa: Aktüel Basım Yayım A.Ş.

Karataş Aracı, Ö., \& Bekçi, i. (2019). MSUGT, TMS/TFRS ve BOBi FRS açısından kavramsal çerçeve ve finansal tabloların sunuluşu standartlarının değerlendirilmesi. Muhasebe ve Vergi Uygulamaları Dergisi, 12(3), 857-884.

KGK (Kamu Gözetimi Muhasebe ve Denetim Standartları Kurumu), http://www.kgk.gov.tr

KGK (Kamu Gözetimi Muhasebe ve Denetim Standartları Kurumu), Büyük ve Orta Boy İ̧̧letmeler İ̧̧in Finansal Raporlama Standardı (BOBi FRS), 29 Temmuz 2017 Tarihli ve 30138 (Mükerrer) Sayılı Resmi Gazete.

KGK (Kamu Gözetimi Muhasebe ve Denetim Standartları Kurumu), Finansal Raporlamaya Illişkin Kavramsal Çerçeve 27 Ekim 2018 tarihli ve 30578 sayılı Resmi Gazete.

KGK (Kamu Gözetimi Muhasebe ve Denetim Standartları Kurumu), Küçük ve Mikro Işletmeler İçin Finansal Raporlama Standardı Taslağı (KÜMi FRS), https://www.kgk.gov.tr/ (Erişim Tarihi: 12 Temmuz 2019).

Kılıç, M. (2019). Borsa İstanbul şirketlerinin kapsamlı gelir raporlama uygulamaları üzerine bir araştırma. Journal of Yaşar University, 14(54), 127-140.

MSUGT (Muhasebe Sistemi 1 Sıra Nolu Uygulama Genel Tebliği), 26/12/1992 tarihli ve 21447 Sayılı Mükerrer Resmi Gazete.

Şahin, M. (2007). İ̧̧letme bilgi sistemi (5. Baskı). Eskişehir: Anadolu Üniversitesi.

TMS 16 “Maddi Duran Varlıklar" Standardı, 15/01/2019 tarihli ve 30656 sayılı (Mükerrer) Resmi Gazete.

TMS 36 "Varlıklarda Değer Düşüklüğü" Standardı, 18/03/2006 tarihli ve 26112 sayılı Resmi Gazete (son güncelleme 19/12/2017 tarih ve 30275 sayılı (Mükerrer) Resmi Gazete).

Yelgen, E., \& Uyar, S. (2018). BOBi FRS açısından maddi duran varlıkların muhasebeleştirilmesi. Muhasebe ve Vergi Uygulamaları Dergisi, Nisan-Özel Sayı, 98-109. 
This Page Intentionally Left Blank 